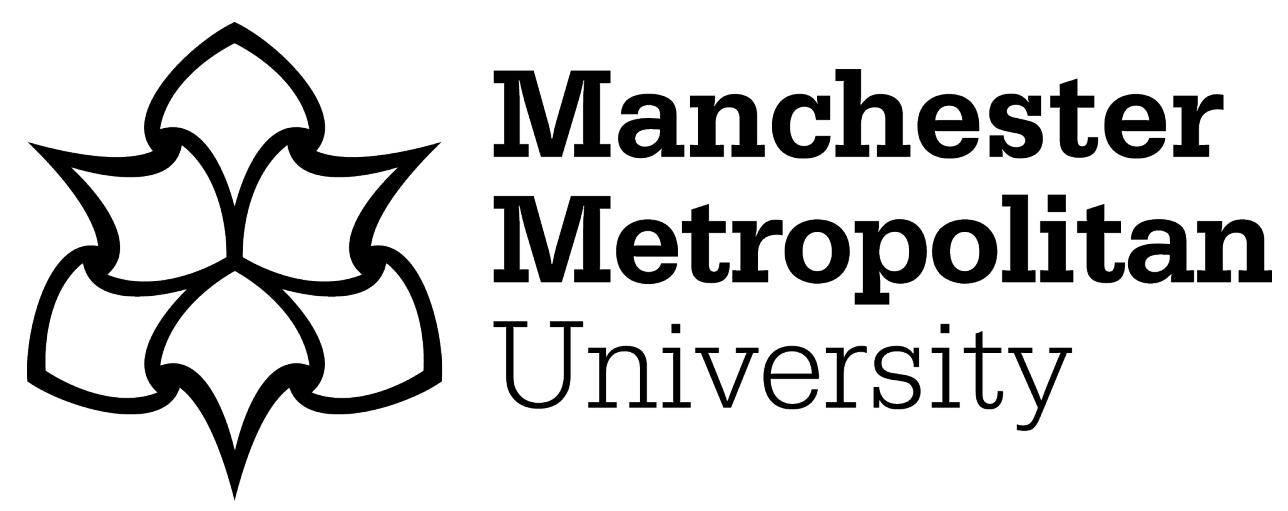

Rampasso, IS, Siqueira, RG, Anholon, R, Silva, D, Quelhas, OLG, Leal Filho, W and Brandli, LL (2019) Some of the challenges in implementing Education for Sustainable Development: perspectives from Brazilian engineering students. International Journal of Sustainable Development and World Ecology, 26 (4). pp. 367-376. ISSN 1350-4509

Downloaded from: https://e-space.mmu.ac.uk/623048/

Version: Accepted Version

Publisher: Taylor \& Francis

DOI: https://doi.org/10.1080/13504509.2019.1570981

Please cite the published version 


\title{
Some of the challenges in implementing Education for Sustainable Development: perspectives from Brazilian engineering students
}

\author{
I. S. Rampasso, R. G. Siqueira, R. Anholon, D. Silva, O. L. \\ G. Quelhas, W. Leal Filho \& L. L. Brandli \\ International Journal of Sustainable Development \& World \\ Ecology
}

To cite this article: I. S. Rampasso, R. G. Siqueira, R. Anholon, D. Silva, O. L. G. Quelhas, W. Leal Filho \& L. L. Brandli (2019): Some of the challenges in implementing Education for Sustainable Development: perspectives from Brazilian engineering students, International Journal of Sustainable Development \& World Ecology

To link to this article: https://doi.org/10.1080/13504509.2019.1570981

\begin{abstract}
This article aims to analyse some of the main challenges evidenced in the insertion of sustainability in engineering courses, according to the view from a sample of Brazilian students. Through a systematic literature review, a set of 10 challenges were structured to base the research instrument (questionnaire). These challenges were evaluated by 91 engineering students who participate in sustainable action programs promoted by Enactus Brazil. The collected data were analysed in terms of the averages assigned and via the multi-criteria decision technique TOPSIS, which allowed ranking the challenges. The averages were higher than 5.0 on the scale used, indicating that the students notice the existence of the challenges in the courses in which they are enrolled. The ranking via TOPSIS presented the most evident challenges: 'Sustainable issues debated only in specific disciplines in a limited extent'; 'Difficulty to integrate disciplines for the broad teaching of sustainability'; 'Lack of practical and real examples of how sustainability can be embedded in the specific context of the course'; and 'Activities and examples presented focus exclusively on environmental issues'. The results presented here may be useful for course coordinators to improve their curriculum; educators to enrich their disciplines from the findings reported here; and researchers interested in the subject can use these findings as a starting point for proposing new teaching techniques. No similar publications were found in the literature, which indicates its originality and contribution to the knowledge base.
\end{abstract}

ARTICLE HISTORY

Received 17 October 2018 Accepted 11 January 2019

KEYWORDS

Sustainable Development (SD); Engineering Education; Educational Challenges

\section{Introduction and theoretical background}

Quality Education is pointed out by the United Nations as one of the 17 Sustainable Development Goals (SDGs) (UN 2015). Aware of its importance, several authors argue that it can be used as an instrument for the training of future professionals who will develop solutions for a better world, in which economic, social and environmental aspects will coexist in harmony (Sivapalan 2016; Guerra 2017; Sandri et al. 2018). According to Svanström et al. (2018) and UNESCO (2017), these professionals must have some key competences, such as: Systems thinking competency; Anticipatory competency; Normative competency; Strategic competency; Collaboration competency; Critical thinking competency; Self-awareness competency; Integrated problem-solving competency. This argument is in line with the definition of SD, accord- ing to which activities that meet the needs of the current generations do not jeopardize future generations (Brundtland 1987; Camioto et al. 2017; Gbededo et al. 2018; Leal Filho et al. 2018; Olawumi and Chan 2018).

In this sense, Education for Sustainable Development (ESD) as a process stands out. Although the fourth goal 
set by the UN strongly emphasizes it, there is a consensus that it contributes decisively to the reach of the other 16 SDGs. According to UNESCO (2017), the learning process for this purpose must contemplate three domains: cognitive, socio-emotional and behavioural.

It is important to note that ESD is not new. The United Nations Educational, Scientific and Cultural Organization (UNESCO) has been working on this concept since the late 1980s. However, the concern and focus around this theme increases every year

(UNESCO 2017), and has gained a new momentum with the launching of the document 'The Future we Want' (Leal Filho, Pace, Manolas 2015). In addition, in recent decades the business environment has been demanding professionals able to critically analyse challenges in the light of SD concepts (Halati and He 2018; Olawumi and Chan 2018).

Currently, organizations' concerns about the impacts of their actions go beyond the manufacturing of their product. In the SD perspective, the whole product life cycle must be considered, from the 

development to the final disposal (Somsuk and Laosirihongthong 2017; Gbededo et al. 2018; Lindow et al. 2018). In this new reality, the need to include new concepts associated with SD in training of new professionals began to be debated by the academic community, including the training of new engineers (Faham et al. 2017; Tejedor et al. 2018). Much is said in the need for the training of engineers to provide them with critical analysis and a vision that considers the impacts of their decisions in the long term and globally (Adomßent et al. 2014; Holm et al. 2015; Lazzarini et al. 2018; Pérez-Foguet et al. 2018; Thürer et al. 2018). Despite the broad debate in the academic community about these needs in the training of new engineers (Ortega-Sánchez et al. 2018; Rampasso et al. 2018; Thürer et al. 2018), there are many challenges for the integration of sustainability into a truly transformative education (Davim and Filho 2016; Rampasso et al. 2018).

Rampasso et al. (2018) in their research, sought to analyse the perception of 112 professors about the main difficulties associated with the insertion of sustainability contents in engineering courses, in Brazil. These authors validated the hypothesis that challenges in the planning phase of actions related to sustainability teaching reflect the challenges in the didactic activities of this teaching. In order to follow the work of Rampasso et al. (2018) and expand the academic debates, this research aims to evaluate the perception of engineering students in relation to the main challenges observed in the insertion of sustainability in their courses. In short, Rampasso et al. (2018) analysed the perception of the professors and now this article analyses the perception of the students. It is important to point out already that the respondents of this research are engineering students and participate in social initiatives developed by Enactus Brazil, an international, non-profit organization that brings together undergraduate students to develop social projects. Its mission is to stimulate students to improve the world through innovation and entrepreneurship and, thus, to contribute to society through their projects. In addition to social sustainability, the environmental and economic dimensions of sustainability are also present in most of its projects (Enactus 2018a, 2018b).

Apart from this introduction and theoretical background which now follows, this article is composed of 3 more sections. Section 2 presents the methodological procedures, which allows the replication of this research. Section 3 presents the results and associated debates and, finally, Section 4 presents the main conclusions of this study. The references used are listed at the end.

\section{Specific challenges faced by Education for Sustainable Development}

The implementation of the transdisciplinarity concept in engineering education faces several challenges, many of them due to the holistic nature of this approach (Shields et al. 2014). It is a concept that not only unites different areas of knowledge but articulates knowledge from different fields (Tejedor et al. 2018). The insertion of sustainability in engineering teaching is characterized by transdisciplinarity and faces many challenges to reach satisfactory results in student training (Shields et al. 2014; Tejedor et al. 2018).

Besides the intrinsic challenge due to the transdisciplinary nature of the theme, the lack of integration among the disciplines of engineering courses also increases the difficulty of an ESD. In this way, issues related to SD are superficially addressed without the deepening that could occur if there were greater connection between the disciplines and greater freedom for students to explore knowledge different from those traditionally presented to them (Schneider et al. 2008; Hopkinson and James 2010; Shields et al. 2014; Guerra 2017; Sivapalan et al. 2017). As a result of this lack of integration, there is an excessive focus on certain aspects of sustainability over other (Guerra 2017).

In this sense, the excessive focus on environmental issues stands out. This is especially important when social sustainability is considered. Social sustainability has historically been little considered in engineering courses. It is clear, therefore, of the loss generated for this concept due to the cited imbalance (Edvardsson Björnberg et al. 2015; Guerra 2017). Considering the ease of explanation and teaching, the social dimension of sustainability presents intrinsic disadvantages when compared to the other dimensions. The environmental impacts generated by a human activity, for example, are more easily measurable than the social impacts and its explanation becomes more tangible to the professor in the classroom from the educational perspective. The concept of social sustainability, itself, is complex to be defined (Edvardsson Björnberg et al. 2015; Seay 2015).

Another important point to highlight is the need for training and professional development of the professors, to enable them to transmit to their students the necessary knowledge; to always consider aspects of sustainability. The absence of this training for engineering professors generates insecurity and lack of interest for the subjects related to SD. And, given their role in the training of future engineers, the consequences of this will have multiplier effects in the future (Schneider et al. 2008; Rydhagen and Dackman 2011; Mulder et al. 2012; Edvardsson Björnberg et al. 2015; Iyer-Raniga and Andamon 2016; Guerra 2017; Mulder 2017; Palacin-Silva et al. 2017; Sivapalan et al. 2017). A proper training would enable professors to provide an enriching education to students on engineering courses.

An enriching education will allow the future engineers to critically think about the challenges of the world. It is hoped that beyond the critical sense, the 
future engineers also possess communication skills, teamwork and be always open to new ideas, generating satisfactory solutions to all stakeholders. The inser-

tion of sustainability in engineering courses can greatly contribute to this differentiated formation, especially when using practical and real examples experienced by society (Hanning et al. 2012; PalacinSilva et al. 2017; Sharma et al. 2017; Sivapalan et al. 2017). The contact of engineering students with real world practices may develop in them the perception of the social relevance of their activities and their knowledge (Jamison et al. 2014; Baroutian et al. 2016).

For these practices to be operationalized, Higher

Education Institutions (HEI) should use an important resource: extracurricular activities. Through them, it is possible for students to develop sustainable actions parallel to their graduation, thus complementing what they learn in the classroom (McCormick et al.

2015; Kieu et al. 2016; Leal Filho et al. 2016).

According to McCormick et al. (2015), these activities help students to expand their knowledge of the subject and to put this knowledge into practice, that is, extracurricular activities provide students the opportunity to understand and execute practices from their functions in a beneficial way to society and to the environment. Leal Filho et al. (2016) corroborate this argument about extracurricular activities.

There are many possibilities for extracurricular activities that can be developed in engineering courses, highlighting in the context of sustainability those focused on improving the life of local communities. Also called service learning, this kind of activity may be used by institutions to engage students in social actions (Goggins 2012). To reach satisfactory results for all stakeholders, however, it is necessary to obtain the university's top management commitment. This will allow the effectiveness and continuity of the projects (Shiel et al. 2016).

Despite the challenges, the partnership between university and local community can be beneficial for both (Hogner and Kenworthy 2010; Dulmus and Cristalli 2012; Ofek 2017). For universities, teaching and research can benefit from greater contact with realworld challenges. In contrast, universities can assist local communities in minimizing or eliminating their challenges (Ofek 2017).

Another important aspect to be highlighted in the insertion of sustainability in engineering education is the long-term commitment, as pointed out by Rydhagen and Dackman (2011) and Tejedor et al. (2018). These authors argue that the development of an ESD ideology requires time and must be continuously supported by the Deans at HEls. In the beginning, a few professors would be more engaged, however, over time, the number of professors participating in the initiatives may increase. Thus, it would be possible to have debates about how the disciplines can be integrated for an ESD, in which the concept of sustainability can be directly or indirectly present in all disciplines.

Given the importance of universities for sustainability teaching, it is essential that these institutions use the concepts of sustainability in their own facilities, serving as examples for their students and the local community (Soares et al. 2015; Hopkins 2016; Dagiliūtè et al. 2018). This is an opportunity to test new ideas in their own laboratory, due to the characteristics of university campuses, which are as small-scale cities. In this way, it could be possible to implement the well succeeded tests on a larger scale, in the cities (Soares et al. 2015; Choi et al. 2017).

All these specific challenges faced by Education for Sustainable Development are presented by the literature. However, analysing the literature, it was verified that the students' perception of how sustainability is inserted in their courses is still an unexplored topic, which provides new research opportunities. Against this background, this research aims to perform this evaluation with a sample of Brazilian students. The next section detail better the procedure to conduct this study.

\section{Methodological procedures}

For the development of this research, the following methodological procedures were used: systematic review of the literature, a survey with 91 engineering students and data analysis using a multi-criterion decision-making technique TOPSIS.

The first stage was characterized by the systematic review of the literature. According to Galvão and Pereira $(2014$, p. 1), a systematic review of the literature is understood as the 'activity of compiling scientific data on a topic', recording the steps taken to allow the procedure replication by other researchers. In this research, the systematic literature review was conducted to identify the main challenges evidenced in the insertion of sustainability in engineering courses. The following terms were combined and used for the search: 'sustainability', 'engineering education', ‘ESD'; 'challenges', 'difficulties', ‘challenges'; 'practice', 'green campus', 'green university', and 'extracurricular activities'. The databases used were: Emerald Insight, ScienceDirect, Taylor and Periódicos Capes. Overall. The research includes articles published from 2000 until 2018.

Based on all the information presented in the previous section, it was possible to structure Table 1 that contemplates the main challenges observed in the insertion of sustainability in higher education, according to the literature. This table will be used as a theoretical framework to evaluate the main challenges observed in the teaching of sustainability in engineering courses in Brazil, according to undergraduate engineering students. Due to the 
Table 1. Challenges faced by engineering education for sustainable development according to the literature

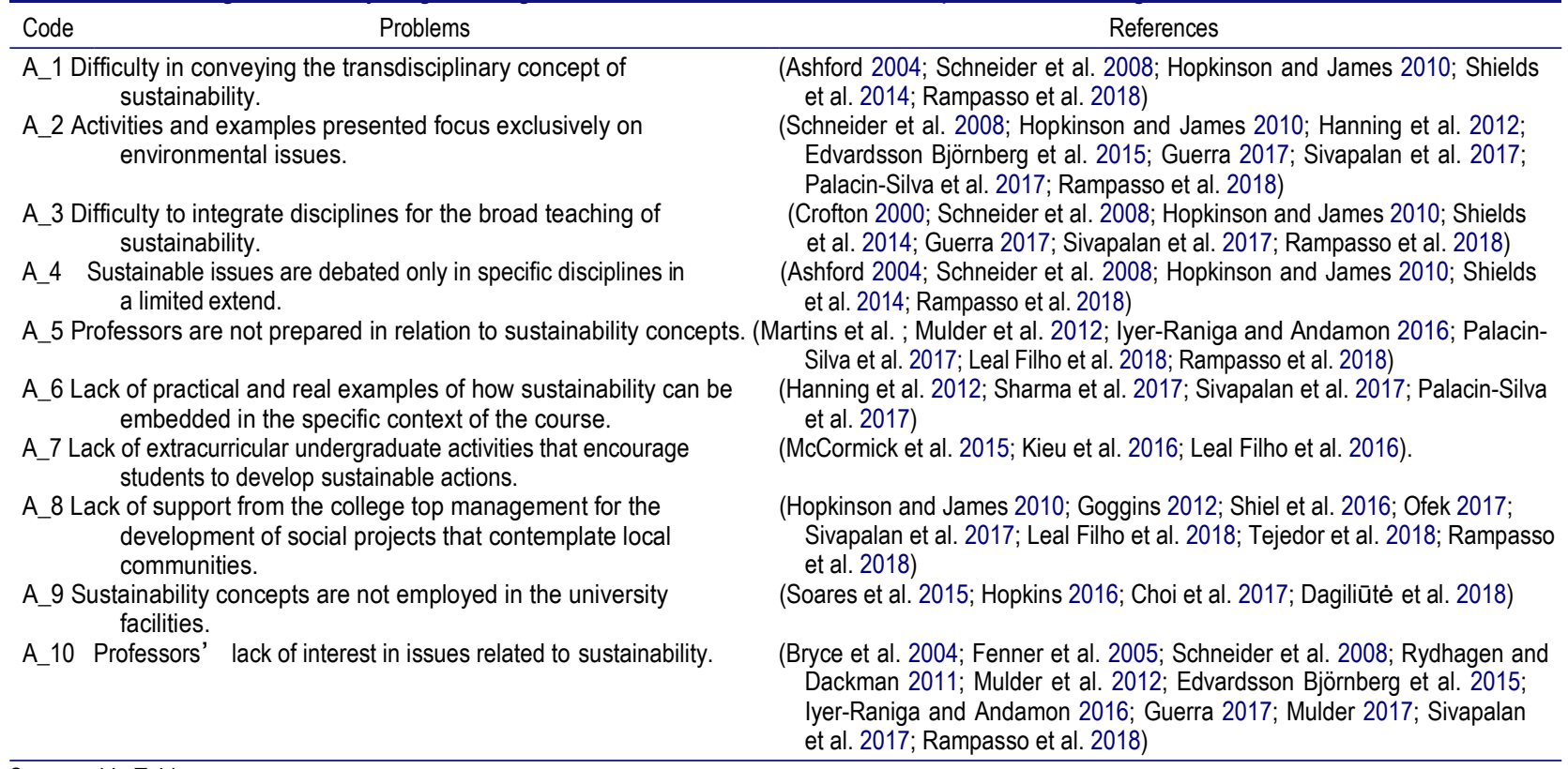

Source: vide Table.

complementary nature of the research of Rampasso et al. (2018), but with a focus on students' perceptions, the systematic review of the literature developed here resulted in some similarities and differences in relation to the aforementioned research, as can be observed in Table 1.

Based on the 30 articles and the 10 challenges presented in Table 1, a research instrument (questionnaire) was structured. It was structured in two parts, the first one related to the characterization of the respondents and the second related to the evaluation of the challenges observed in the insertion of sustainability in engineering courses. For the first part, respondents should provide the following information: name, engineering course, educational institution, and region of the country and years of experience in sustainable projects developed with Enactus Brazil. In the second part, the respondent should indicate on a scale of 0 to 10 how much they observed of each challenge in the engineering course in which they are enrolled. At the extremes, grade 0 indicates the non-observation of the challenge, while grade 10 indicates intense observation of the challenge. Once the research instrument was structured and following the recommendations of Gil (2010), the questionnaire was submitted to a pre-test with professors. The purpose of this initiative was to find possible errors and improve the understanding of the questions to be asked. Finally, before starting to collect data, the research instrument was submitted for the appreciation of an Ethics Committee, since this practice is characterized as necessary for conducting surveys in Brazil.

After the approval of the Research Ethics Committee, data collection was started. The electronic questionnaire sent through the Google Forms platform and was available to respondents for a period of 4 months. A student of scientific initiation assisted the researchers in data collection. The invitation to respond to the survey was sent only for engineering students, totalizing 152 students who participate in the Enactus Brazil projects and are involved with sustainable actions developed by this organization. Present in more than 1,730 university programs in 36 countries, Enactus has approximately 72,000 students annually and 550 partnerships (between partner companies and individual volunteers) (Enactus 2018a). Currently in Brazil, Enactus has 120 teams, with a total of 2,800 students and 210 projects. The organization

is present in more than 20 Brazilian States and has units in more than 100 Brazilian HEI (Enactus 2018b).

So, these students have experience in projects that involve social sustainability and often also the environmental and economic aspects of sustainability. Therefore, they were considered able to make a critical analysis of their courses. It is understood that, the greater the student's experience in these initiatives, the greater their ability to perform a critical analysis about ESD and this factor will be considered in the data analysis.

After 4 months, 91 questionnaires were considered valid, characterizing a response rate of $59.87 \%$. The data were tabulated in Excel spreadsheets, and the respondents were divided according to the years of experience they had with Enactus Brazil. The first group of respondent students had more than 3 years of experience with the organization, the second group had between 1 and 3 years of experience and, lastly, the third group had up to 1 year of experience. It was assumed that the greater the experience of the students, the greater their ability 
to know the real challenges in their courses and, therefore, greater consideration should be given to their perceptions. The means for each group of respondents were calculated and used in the data analysis.

The technique used for data analysis was TOPSIS, designed in 1981 by Ching-Lai Hwang and Kwangsun Yoon (Hwang and Yoon 1981; Yoon and Kim 2017). According to Singh et al. (2016), TOPSIS allows the ordering of alternatives considering different analysis criteria. Such criteria may have weights denoting different degrees of importance. Thus, TOPSIS may be used as a tool to base decisions and increase the efficiency of decision-making (Lima Junior and Carpinetti 2015). For this study, each of the 10 challenges cited had three average scores measured by the aforementioned groups and TOPSIS was responsible for weighting these values. The code used to represent each challenge in TOPSIS is shown in Table 1 . In consensus meetings, the authors of this article decided to assign $50 \%$ weights to the means measured by the first group of respondents, $30 \%$ to the means measured by the second group and, finally, $20 \%$ for the third group.

The calculations performed for the ordering of the challenges through TOPSIS technique followed the steps presented by Singh et al. (2016). The first step was characterized by the structuring of a matrix $D$, in which the elements (xij) were identified by an alternative (i) and by an analysis criterion (j). In the case of this research, the alternatives corresponded to the 10 challenges mentioned in the literature and the criteria corresponded to the three means measured by each group of respondents for each of the challenges.

A matrix with 30 values was thus obtained. The mathematical representation of the matrix is shown by means of Equation 1 (Singh et al. 2016, p. 24).

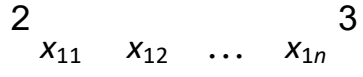

$$
\begin{aligned}
& \text { D } 1 / 4 q^{4} \begin{array}{cccc}
x_{21} & x_{22} & \ldots & x_{2 n} \\
\ldots & \ldots & \ldots & \ldots \\
x_{m 1} & x_{m 2} & \ldots & x_{m n}
\end{array}
\end{aligned}
$$

The second step was characterized by the normalization of Matrix D via Equation 2 (Singh et al. 2016, p. 25), resulting in a new matrix called Matrix $R$ - Equation 3 (Singh et al. 2016, p. 25). The mathematical representations of Equation 2 and matrix $\mathrm{R}$ are given below.

$$
\begin{aligned}
& r_{i j} 1 / 4 x_{i j}=\underset{i 1 / 41}{\operatorname{Qr} x_{i j}^{2}} \\
& 2 r_{11} \quad r_{12} \quad \ldots \quad r_{1 n}{ }^{3}
\end{aligned}
$$

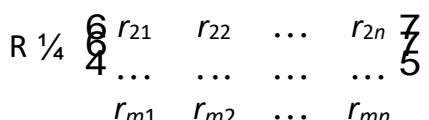

The third step was characterized by the weighting of the values of the matrix $R$ and, for this, Equation 4 was used (Singh et al. 2016, p. 25). The new matrix obtained was denominated Matrix V. It is worth noting again that the following weights were attributed: $50 \%$ for the averages measured by group $1,30 \%$ for the means measured by group 2 and $20 \%$ for the means measured by group 3 . The mathematical representations of Equation 4 and Matrix $V$ - Equation 5 (Singh et al. 2016, p. 25) are shown below.

$$
v_{i j} 1 / 4 \quad w_{j} r_{i j}
$$

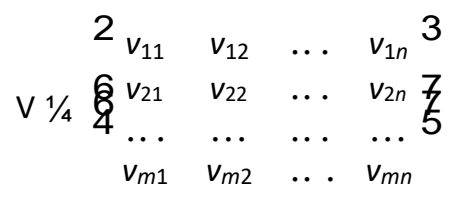

The fourth step was marked by the determination of the positive $\left(\mathrm{vj}^{+}\right)$and negative $\left(\mathrm{vj}^{-}\right)$ideal solutions. This step was operationalized through the identification of the maximum and minimum values existing in Matrix $V$ for each of the analysis criteria. This procedure was necessary to perform the fifth step, in which the positive and negative Euclidean distances of each alternative were calculated. Equations 6 and 7 (Singh et al. 2016, p. 25) present the calculus made to find Euclidean distance from positive ideal solution and Euclidean distance from negative ideal solution, respectively.

$$
\begin{array}{rrr}
s_{i}^{* 1 / 4} \underset{j}{ } y_{j}^{*}-v_{j}^{p} 2^{1=2} & \\
& \times \\
s_{i}^{0} 1 / 4 & { }_{j} v_{i j}^{0}-v_{j}^{-} &
\end{array}
$$

From the results obtained for the positive and negative Euclidean distances, it was possible to calculate the indicator $\mathrm{Ci}^{*}$ (step 6) and, through it, to order the 10 challenges mentioned in the literature according to students' perception (step 7). It is important to note that the values of $\mathrm{Ci}^{*}$ must be between 0 and 1 . The calculation of the indicator $\mathrm{Ci}^{*}$ was operationalized through Equation 8 (Singh et al. 2016, p. 25).

$$
c_{i}^{*} 1 / 4\left(s_{s_{i}^{*}}^{s^{0}} \frac{i}{\mathrm{Ps} s_{i}^{0}}\right)
$$

Once the ordering of the 10 challenges observed in the insertion of sustainability in engineering courses according to Brazilian students was obtained, discussions were carried out in the light of the literature.

\section{Results and discussion}

This section is dedicated to present the results and discussion. Initially, we present a profile of engineering students who responded to the survey. In the sequence, the characterization of the sample and the calculations performed by TOPSIS are presented for ordering the 
challenges according to the degree of identification measured by the students. Once the 10 challenges were ordered, discussions were held in the light of the literature.

\section{Profile of the engineering students}

The courses attended by the respondents is as follows: Chemical Engineering (24.17\%), Civil Engineering (13.18\%), Mechanical Engineering (12.08\%), Production Engineering (12.08\%) and Electrical Engineering (8.79\%) highlight. Together, other Engineering courses as Mechatronics Engineering, Materials Engineering, Biotechnology Engineering totalized $29.7 \%$ of the sample.

Regarding respondents' time of experience in Enactus, $42.9 \%$ of them had up to 1 year of experience; $48.4 \%$ had between 1 and 3 years of experience; and $8.8 \%$ had 3 years or more of experience. It is important to note that two respondents had 5 years of experience. This is a coherent distribution since students participate in the projects during the undergraduate course, which in Brazil lasts an average of 5 years for engineering courses.

In addition, it should be noted that the 91 respondents are enrolled in 17 different Brazilian higher education institutions. Another relevant piece of research was the Brazilian region of these institutions: $60.4 \%$ of the respondents are from the Southeast; $14.3 \%$ of the South; $14.3 \%$ from the North and $11 \%$ from the Northeast. There was no respondent from the Midwest region of the country. It is possible to notice a coherence in the distribution of the respondents among the regions represented in the research, since the Southeast of Brazil is the most populous region of the country.

\section{Results from TOPSIS technique}

As pointed out in the methodological procedures section, the TOPSIS technique was used for data analysis and challenge ordering. Thus, data collected through the survey were divided into three different groups, according to respondents' experience time (group 1: over 3 years of experience, group 2: between 1 and 3 years of experience, group 3: up to 1 year of experience) and the grades averages assigned by each group were calculated (step 1). The calculated averages are presented in Table 2 .

Step 2 was characterized by the normalization of the values from Table 2, using the Equation 1. The result was the matrix $R$ of this research. Table 3 presents the matrix $R$, with normalized values.

In step 3 weights were assigned to each group of respondents. As mentioned in section 2 of this article, students with more than 3 years of experience received weight of $50 \%$, respondents who were in Enactus between 1 and 3 years received weight of $30 \%$ and
Table 2. Averages of the scores attributed by each group of respondents.

\begin{tabular}{lccc}
\hline Problems & Over 3 years & Between 1 and 3 years & Up to 1 year \\
\hline A_1 & 6.25 & 6.39 & 6.05 \\
A_2 & 7.63 & 5.82 & 5.56 \\
A_3 & 7.63 & 7.43 & 7.00 \\
A_4 & 7.88 & 8.02 & 7.64 \\
A_5 & 6.00 & 7.02 & 6.18 \\
A_6 & 8.00 & 7.11 & 6.46 \\
A_7 & 5.88 & 6.75 & 6.05 \\
A_8 & 5.88 & 7.20 & 7.10 \\
A_9 & 5.75 & 6.91 & 6.03 \\
A_10 & 5.13 & 6.30 & 5.90 \\
\hline
\end{tabular}

Source: Authors.

Table 3. Matrix $\mathrm{R}$ with normalized values.

\begin{tabular}{lccc}
\hline Problems & rij (over 3 years) & $\begin{array}{c}\text { rij (between 1 and } \\
\text { 3 years) }\end{array}$ & rij (up to 1 year) \\
\hline A_1 & 0.30 & 0.29 & 0.30 \\
A_2 & 0.36 & 0.27 & 0.27 \\
A_3 & 0.36 & 0.34 & 0.34 \\
A_4 & 0.37 & 0.37 & 0.38 \\
A_5 & 0.28 & 0.32 & 0.30 \\
A_6 & 0.38 & 0.33 & 0.32 \\
A_7 & 0.28 & 0.31 & 0.30 \\
A_8 & 0.28 & 0.33 & 0.35 \\
A_9 & 0.27 & 0.32 & 0.30 \\
A_10 & 0.24 & 0.29 & 0.29 \\
\hline
\end{tabular}

Source: Authors.

respondents with up to 1 year of experience received weight of $20 \%$. Thus, matrix V was obtained. Matrix $\mathrm{V}$ and their respective values are shown in Table 4.

In sequence, Table 5 presents the Positive Ideal Solution and the Negative Ideal Solution, relative to step 4. The data from Table 5 are necessary to calculate the items of Table 6, that presents the distances from the Positive Ideal Solution, distances from the Negative Ideal Solutions and Coefficient Ci* (steps 5 and 6).

Finally, in step 7 , the ordering of the difficulties was performed from the Coefficient $\left(\mathrm{Ci}^{*}\right)$ values obtained. The result of this ranking is presented in Table 7.

\section{Difficulties and challenges for ESD}

The first discussion here is regarding Table 2, which presents the averages measured without considering the weights assigned to each group. Through it, it is possible to see that all the identified challenges have at least a mean intensity, on a scale of 0 to 10 , showing that for the respondent students many challenges exist in the attempt to insert sustainability in the curricula of their courses. This opens a clear warning to educators and course coordinators that there is much to be done and a long way to go. The difficulty of inserting sustainability contents in engineering courses is corroborated by authors such as Shields et al. (2014) and Holgaard et al. (2016).

Secondly, the results generated by TOPSIS can be debated, remembering that it has ordered the challenges according to the grade given by the respondents and weights assigned to the groups. 
Table 4. Weighted values.

\begin{tabular}{lccc}
\hline Problems & $\begin{array}{c}\text { rij (over } \\
3 \text { years) }\end{array}{ }^{*} 0.50$ & $\begin{array}{r}\text { rij (between 1 and } \\
3 \text { years) }\end{array}$ & $\begin{array}{c}\text { rij (up to } \\
1 \text { year) }\end{array}$ \\
\hline A_1 & 0.15 & 0.09 & 0.06 \\
A_2 & 0.18 & 0.08 & 0.05 \\
A_3 & 0.18 & 0.10 & 0.07 \\
A_4 & 0.19 & 0.11 & 0.08 \\
A_5 & 0.14 & 0.10 & 0.06 \\
A_6 & 0.19 & 0.10 & 0.06 \\
A_7 & 0.14 & 0.09 & 0.06 \\
A_8 & 0.14 & 0.10 & 0.07 \\
A_9 & 0.14 & 0.09 & 0.06 \\
A_10 & 0.12 & 0.09 & 0.06
\end{tabular}

Source: Authors.

Table 5. Positive ideal solution and negative ideal solution to criteria access.

\begin{tabular}{lccc}
\hline Solution Criteria & $\begin{array}{c}\text { Over } \\
\text { 3 years }\end{array}$ & $\begin{array}{c}\text { Between 1 and } \\
\text { 3 years }\end{array}$ & $\begin{array}{c}\text { Up to } \\
1 \text { year }\end{array}$ \\
\hline Positive Ideal Solution $\left(\mathrm{vj}^{+}\right)$ & 0.19 & 0.11 & 0.08 \\
Negative Ideal Solution $\left(\mathrm{vj}^{-}\right)$ & 0.12 & 0.08 & 0.05 \\
\hline
\end{tabular}

Source: Authors.

Table 6. Distances from the positive ideal solution, distances from the negative ideal solutions and coefficient $\mathrm{Ci}^{*}$.

\begin{tabular}{lccc}
\hline Problems & $\begin{array}{c}\text { Distance from the } \\
\text { Positive Ideal } \\
\text { Solution }\left(\mathrm{Si}^{*}\right)\end{array}$ & $\begin{array}{c}\text { Distance from the } \\
\text { Negative Ideal } \\
\text { Solution }\left(\mathrm{Si}^{\prime}\right)\end{array}$ & $\begin{array}{c}\text { Coefficient } \\
\left(\mathrm{Ci}^{*}\right)\end{array}$ \\
\hline A_1 & 0.05 & 0.03 & 0.36 \\
A_2 & 0.04 & 0.06 & 0.61 \\
A_3 & 0.01 & 0.06 & 0.83 \\
A_4 & 0.00 & 0.07 & 0.96 \\
A_5 & 0.05 & 0.03 & 0.35 \\
A_6 & 0.02 & 0.07 & 0.81 \\
A_7 & 0.06 & 0.02 & 0.29 \\
A_8 & 0.05 & 0.03 & 0.37 \\
A_9 & 0.06 & 0.02 & 0.27 \\
A_10 & 0.07 & 0.01 & 0.09 \\
\hline
\end{tabular}

Source: Authors.

A challenge listed in the last position does not mean that it should not be debated by educators, but rather that it has been identified as less intensive vis-à-vis others. In this article, the focus will be the challenges that obtained coefficient $\left(\mathrm{Ci}^{*}\right)$ greater than 0.5 . As highlighted in Table 7 , the challenges that were observed more intensely by the students, considering the mentioned weightings, are: 'Sustainable issues debated only in specific disciplines in a limited extent'; 'Difficulty to integrate disciplines for the broad teaching of sustainability'; 'Lack of practical and real examples of how sustainability can be embedded in the specific context of the course'; and 'Activities and examples presented focus exclusively on environmental issues'.

The first two challenges highlighted by the TOPSIS analysis correlate in a certain way, since they reflect the 'quick' attempt to insert 'sustainability' in curricular matrices of engineering courses without major modifications in the curricular structures and without great debates between professors. The allocation of specific disciplines in a limited extent is simpler to be operationalized by the course coordinators than the
Table 7. Ranking of the challenges.

\begin{tabular}{|c|c|c|c|}
\hline Position & $\left(\mathrm{C}_{i}^{*}\right)$ & Code & Challenges \\
\hline $1^{0}$ & \multicolumn{3}{|c|}{$\begin{array}{c}0.961856 \text { A_4 Sustainable issues debated only in specific } \\
\text { disciplines in a limited extend. }\end{array}$} \\
\hline $2^{\circ}$ & \multicolumn{3}{|c|}{$\begin{array}{l}0.826718 \text { A_3 Difficulty to integrate disciplines for the } \\
\text { broad teaching of sustainability. }\end{array}$} \\
\hline $3^{\circ}$ & 0.806368 & A_6 & $\begin{array}{l}\text { Lack of practical and real examples of how } \\
\text { sustainability can be embedded in the } \\
\text { specific context of the course. }\end{array}$ \\
\hline $4^{\circ}$ & 0.611937 & & $\begin{array}{l}\text { Activities and examples presented focus } \\
\text { exclusively on environmental issues. }\end{array}$ \\
\hline $5^{\circ}$ & 0.367353 & A_8 & $\begin{array}{l}\text { Lack of support from the college top } \\
\text { management for the development of } \\
\text { social projects that contemplate local } \\
\text { communities. }\end{array}$ \\
\hline $6^{\circ}$ & \multirow{3}{*}{\multicolumn{3}{|c|}{$\begin{array}{l}0.361963 \text { A_1 Difficulty in conveying the } \\
\text { transdisciplinary concept of } \\
\text { sustainability. }\end{array}$}} \\
\hline $7^{0}$ & & & \\
\hline $8^{\circ}$ & & & \\
\hline & \multicolumn{3}{|c|}{ 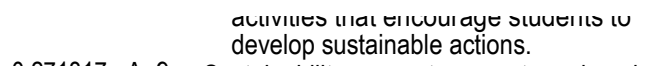 } \\
\hline $9^{\circ}$ & 0.271817 & A_9 & $\begin{array}{l}\text { Sustainability concepts are not employed } \\
\text { in the university facilities. }\end{array}$ \\
\hline $10^{\circ}$ & 0.089885 & A_10 & $\begin{array}{l}\text { Professors' lack of interest in issues related } \\
\text { to sustainability. }\end{array}$ \\
\hline
\end{tabular}

Source: Authors.

modification and integration of the curricular matrix. This last action requires intense participation of the professors, consensus among them regarding importance of the ESD and attempt to integrate content in a transdisciplinary way, which according to Hopkinson and James (2010) and Mulder (2017) is not always

easy. It is worth remembering that the professors resistance to change is remarkable in many engineer-

ing courses (Edvardsson Björnberg et al. 2015;

Rampasso et al. 2018).

The third and fourth challenges highlighted by TOPSIS are also a consequence of the lack of debates among the professors. The greater the intensity of these discussions in a course, the greater the integration of the disciplines, the greater the understanding of how the concepts of each engineering can contribute to SD, the greater the involvement of students in projects with local communities and the better the results of these projects. Successful cases are being disclosed and generated in the engineering courses and, over time, they are used as didactic examples for the training of other students. A wide variety of cases will provide a broad discussion of how more complex aspects of sustainability (such as social) can be evaluated and this will increasingly enrich the training of new students. Discussions will go beyond examples that merely present sustainability as a strictly environmental issue (Sivapalan et al. 2017; Rampasso et al. 2018).

\section{Conclusion}

This article aimed to study the main challenges observed in the ESD in engineering courses offered by Brazilian institutions, based on students' perceptions. It 
presents a complementary character to the research of Rampasso et al. (2018). To meet the research objectives, a set of 10 challenges associated with the insertion of ESD were identified from the literature and they served as parameters for conducting a survey with 91 students enrolled in 17 different engineering courses. These students were allocated in groups according to the years of experience they had in the context of Enactus Brazil initiatives.

The simple analysis of data through averages attributed by the group showed that many challenges are observed by the students in their courses, since on a scale of 0 to 10 none of the challenges obtained averages below 5.0. When ordered via TOPSIS, four challenges stood out, namely:

(1) 'Sustainable issues are debated only in specific disciplines in a limited extent';

(2) 'Difficulty to integrate disciplines for the broad teaching of sustainability';

(3) 'Lack of practical and real examples of how sustainability can be embedded in the specific context of the course'; and

(4) 'Activities and examples presented focus exclusively on environmental issues'.

When analysing these four challenges, it is possible to note that they are correlated and have a common root: the limited participation of professors in efforts towards better inserting sustainability in the engineering courses in which they work.

The main conclusion reached from the results of this article is that there is much to be done to make the Brazilian $\mathrm{HEI}$ able to effectively insert sustainability into their engineering courses, providing a truly transformative training. The study of Rampasso et al. (2018) had shown that there is a causality between planning difficulties and difficulties observed in didactic practice and now, in a complementary way, this article

shows that engineering students can clearly show challenges in the courses in which they are enrolled.

The exploratory nature of this research that aims to better understand the insertion of sustainability in engineering courses and which used Brazil as a sample, may also be undertaken in other countries. Indeed, further studies may be undertaken and which

may allow a profile of the extent to which sustainability is being considered in other developing countries may prove useful in guiding further action.

At this stage, it is important to mention the limitations of this study. The first one refers to the size sample. Data from 91 engineering students who develop social projects with Enactus Brazil were analysed. Due to the nature and scope of the study, it is assumed that the sample is satisfactory and that students who are engaged in social projects can evaluate what was requested. Another assumption made was that the greater the students' experience in Enactus Brazil, the greater the validity of their answers and therefore the greater the weighting in the TOPSIS analysis. Different sizes of samples, different students and different weights assigned can lead to different results.

As far as the way forward is concerned, some measures could be implemented to address the difficulties identified in the study. These may be as follows:

a. Better provision of in-service training to lecturers/professors at universities, so that they are made more familiar with the didactic tools and methods to include sustainability in engineering programmes;

b. Greater use of the SDGs as teaching tools, catering for an interdisciplinary and cross-thematic handling of sustainability issues at universities;

c. More intensive interactions among universities, to better exchange information and disseminate good practice.

The implications of this work and the relevance of its results are threefold:

- Firstly, the results obtained and here presented can be useful for course coordinators, educators and researchers interested in the subject.

- Secondly, the data gathered may assist course coordinators in improving the curriculum of engineering courses.

- Thirdly, researchers, may use them as a starting point for proposing new teaching techniques.

Unfortunately, students' perception of the main challenges observed in the ESD in engineering courses is still little explored, and there is therefore ample scope for discussion. Further are needed in this field, so as to provide a long-term contribution to the weak knowledge base observed today.

\section{Disclosure statement}

No potential conflict of interest was reported by the authors.

\section{ORCID}

O. L. G. Quelhas (D) http://orcid.org/0000-0001-6816-1677

W. Leal Filho (1) http://orcid.org/0000-0002-1241-5225

\section{References}

Adomßent M, Fischer D, Godemann J, Herzig C, Otte I, Rieckmann M, Timm J. 2014. Emerging areas in research on higher education for sustainable development e management education, sustainable consumption and 
perspectives from Central and Eastern Europe. J Clean Prod. 62:1-7.

Ashford NA. 2004. Major challenges to engineering education for sustainable development. Int J Sustain High Educ. 5(3):239-250. http://www.emeraldinsight.com/doi/10. $1108 / 14676370410546394$.

Baroutian S, Kensington-Miller B, Wicaksana F, Young BR. 2016. Bridging theory with real world research experience: coteaching engineering biotechnology with R\&D professionals. Educ Chem Eng. 16(2006):9-16. doi:10.1016/j. ece.2016.05.002.

Brundtland G. 1987. Our common future. Oslo: Oxford University Press.

Bryce P, Johnston S, Yasukawa K. 2004. Implementing a program in sustainability for engineers at university of technology, sydney. int j sustain high educ. 5(3):267-277. http://www. emeraldinsight. Com/doi/.10:1108/14676370410546411.

Camioto FDC, Mariano EB, Da DNR. 2017. Sustainability improvement opportunities in Brazilian sectors: analysis of DEA slacks. Brazilian J Oper Prod Manag. 14(3):363. https://bjopm.emnuvens.com.br/bjopm/article/view/ 356.

Choi Y, Oh M, Kang J, Lutzenhiser L. 2017. Plans and living practices for the green campus of portland state university. Sustainability. 9(2):252. http://www.mdpi. com/2071-1050/9/2/252.

Crofton FS. 2000. Educating for sustainability: opportunities in undergraduate engineering. J Clean Prod. 8(5):397405. Available from: http://linkinghub.elsevier.com/ retrieve/pii/S0959652600000433

Dagiliūtè R, Liobikienè G, Minelgaitè A. 2018. Sustainability at universities: students' perceptions from green and non-green universities. J Clean Prod. 181:473-482.

Davim JP, Filho WL. 2016. Challenges in higher education for sustainability [Internet]. Davim JP, Leal Filho W, editors. Cham: Springer International Publishing. doi:10.1007/9783-319-23705-3.

Dulmus CN, Cristalli ME. 2012. A university-community partnership to advance research in practice settings: the HUB research model. Res Soc Work Pract. 22(2):195-202.

Edvardsson Björnberg K, Skogh I-B, Strömberg E. 2015. Integrating social sustainability in engineering education at the KTH royal institute of technology. Int J Sustain High Educ. 16(5):639-649. doi:10.1108/IJSHE-01-2014-0010.

Enactus. 2018a. Enactus [Internet]. [accessed 2018 Sep 21]. http://enactus.org/.

Enactus. 2018b. Enactus Brasil [Internet]. [accessed 2018 Sep 20]. http://www.enactus.org.br/.

Faham E, Rezvanfar A, Movahed Mohammadi SH, Rajabi Nohooji M. 2017. Using system dynamics to develop education for sustainable development in higher education with the emphasis on the sustainability competencies of students. Technol Forecast Soc Change. 123:307326. doi:10.1016/j.techfore.2016.03.023

Fenner RA, Ainger CM, Cruickshank HJ, Guthrie PM. 2005. Embedding sustainable development at Cambridge University Engineering Department. Int J Sustain High Educ. 6(3):229-241. http://www.emeraldinsight.com/doi/ 10.1108/14676370510607205.

Galvão TF, Pereira MG. 2014. Revisões sistemáticas da literatura: passos para sua elaboração. Epidemiol e Serviços Saúde. 23 (1):183-184. http://scielo.iec.pa.gov.br/scielo.php?script=sci_ arttext\&pid=S1679-49742014000100018\&lng=en\&nrm= iso\&tlng=en.

Gbededo MA, Liyanage K, Garza-Reyes JA. 2018. Towards a life cycle sustainability analysis: a systematic review of approaches to sustainable manufacturing. J Clean Prod.
184:1002-1015. http://linkinghub.elsevier.com/retrieve/ pii/S0959652618306486.

Gil A. 2010. Como Elaborar Projetos de Pesquisa. São Paulo: Editora Atlas.

Goggins J. 2012. Engineering in communities: learning by doing. Campus-Wide Inf Syst. 29(4):238-250.

Guerra A. 2017. Integration of sustainability in engineering education. Int J Sustain High Educ. 18(3):436-454. doi:10.1108/IJSHE-02-2016-0022.

Halati A, He Y. 2018. Intersection of economic and environmental goals of sustainable development initiatives. J Clean Prod. http://linkinghub.elsevier.com/retrieve/pii/ S0959652618310096.

Hanning A, Priem Abelsson A, Lundqvist U, Svanström M. 2012. Are we educating engineers for sustainability? Int J Sustain High Educ. 13(3):305-320. doi:10.1108/14676371211242607.

Hogner RH, Kenworthy AL. 2010. Moving forward together in sustainable, effective, and partnershiporiented ways. Int J Organ Anal. 18(2):245-266. doi:10.1108/19348831011046290.

Holgaard JE, Hadgraft R, Kolmos A, Guerra A. 2016. Strategies for education for sustainable development Danish and Australian perspectives. J Clean Prod. 112:34793491. doi:10.1016/j.jclepro.2015.09.063

Holm T, Vuorisalo T, Sammalisto K. 2015. Integrated management systems for enhancing education for sustainable development in universities: a memetic approach. J Clean Prod. 106:155-163. doi:10.1016/j.jclepro.2014.03.048

Hopkins EA. 2016. Barriers to adoption of campus green building policies. Smart Sustain Built Environ. 5 (4):340351. doi:10.1108/SASBE-07-2016-0016.

Hopkinson P, James P. 2010. Practical pedagogy for embedding ESD in science, technology, engineering and mathematics curricula. Int J Sustain High Educ. 11(4):365-379. doi:10.1108/14676371011077586.

Hwang C-L, Yoon K. 1981. Multiple attribute decision making [Internet]. Berlin (Heidelberg): Springer. doi:10.1007/ 978-3-642-48318-9.

Iyer-Raniga U, Andamon MM. 2016. Transformative learning: innovating sustainability education in built environment. Int J Sustain High Educ. 17(1):105-122. doi:10.1108/IJSHE09-2014-0121.

Jamison A, Kolmos A, Holgaard JE. 2014. Hybrid learning: an integrative approach to engineering education. J Eng Educ. 103(2):253-273.

Kieu TK, Singer J, Gannon TJ. 2016. Education for sustainable development in Vietnam: lessons learned from teacher education. Int J Sustain High Educ. 17(6):853-874. doi:10.1108/IJSHE-05-2015-0098.

Lazzarini B, Pérez-Foguet A, Boni A. 2018. Key characteristics of academics promoting sustainable human development within engineering studies. J Clean Prod. 188:237252.

Leal Filho W, Manolas E, Pace P. 2015. The future we want. Int J Sustain High Educ. 16(1):112-129. http://www.emer aldinsight.com/doi/10.1108/IJSHE-03-2014-0036.

Leal Filho W, Pallant E, Enete A, Richter B, Brandli LL. 2018. Planning and implementing sustainability in higher education institutions: an overview of the difficulties and potentials. Int J Sustain Dev World Ecol. 25:713-721. doi:10.1080/13504509.2018.1461707

Leal Filho W, Shiel C, Paço A. 2016. Implementing and operationalising integrative approaches to sustainability in higher education: the role of project-oriented learning. J Clean Prod. 133:126-135. doi:10.1016/j.jclepro.2016.05.079

Lima Junior FR, Carpinetti LCR. 2015. Uma comparação entre os métodos TOPSIS e Fuzzy-TOPSIS no apoio à tomada de 
decisão multicritério para seleção de fornecedores. Gestão \& Produção. 22(1):17-34. http://www.scielo.br/ sciel o.php ?script $=$ sci_arttext \&pid=S 0104 530X2015000100017\&lng=pt\&tlng=pt.

Lindow K, Kaluza A, Stark R. 2018. Study on sustainability developments in industrial practice. Procedia Manuf. 21:345-352. http://linkinghub.elsevier.com/retrieve/pii/ S2351978918301653.

Martins AA, Mata TM, Costa CAV. 2006. Education for sustainability: challenges and trends. Clean Technol Environ Policy. 8(1):31-37. http://link.springer.com/10.1007/ s10098-005-0026-3.

McCormick M, Bielefeldt AR, Swan CW, Paterson KG. 2015. Assessing students' motivation to engage in sustainable engineering. Int J Sustain High Educ. 16(2):136-154. doi:10.1108/IJSHE-06-2013-0054.

Mulder KF. 2017. Strategic competences for concrete action towards sustainability: an oxymoron? Engineering education for a sustainable future. Renew Sustain Energy Rev. 68:1106-1111. doi:10.1016/j.rser.2016.03.038

Mulder KF, Segalàs J, Ferrer-Balas D. 2012. How to educate engineers for/in sustainable development. Int J Sustain High Educ. Svanström M, editor. 13(3):211-218. doi:10.1108/14676371211242535.

Ofek Y. 2017. Evaluating social exclusion interventions in university-community partnerships. Eval Program Plann. 60:46-55. doi:10.1016/j.evalprogplan.2016.09.004

Olawumi TO, Chan DWM. 2018. A scientometric review of global research on sustainability and sustainable development. J Clean Prod. 183:231-250. doi:10.1016/j.jclepro.2018.02.162

Ortega-Sánchez M, Moñino A, Bergillos RJ, Magaña $P$, Clavero M, Díez-Minguito M, Baquerizo A. 2018. Confronting learning challenges in the field of maritime and coastal engineering: towards an educational methodology for sustainable development. J Clean Prod. 171:733742. doi:10.1016/j.jclepro.2017.10.049

Palacin-Silva MV, Seffah A, Porras J. 2017. Infusing sustainability into software engineering education: lessons learned from capstone projects. J Clean Prod. http://linkin ghub.elsevier.com/retrieve/pii/S0959652617312489.

Pérez-Foguet A, Lazzarini B, Giné R, Velo $E$, Boni A, Sierra $M$, Zolezzi G, Trimingham R. 2018. Promoting sustainable human development in engineering: assessment of online courses within continuing professional development strategies. J Clean Prod. 172:4286-4302.

Rampasso IS, Anholon R, Silva D, Cooper Ordoñez RE, Quelhas OLG, Leal Filho W, Santa-Eulália LA. 2018. An analysis of the difficulties associated to sustainability insertion in engineering education: examples from HEls in Brazil. J Clean Prod. 193:363-371. http://linkinghub.else vier.com/retrieve/pii/S0959652618314100.

Rydhagen B, Dackman C. 2011. Integration of sustainable development in sanitary engineering education in Sweden. Eur J Eng Educ. 36(1):87-95. doi:10.1080/ 03043797.2010.539678.

Sandri O, Holdsworth S, Thomas I. 2018. Assessing graduate sustainability capability post-degree completion: why is it important and what are the challenges? Int J Sustain High Educ. 19(1):2-14.

Schneider J, Leydens JA, Lucena J. 2008. Where is 'community'?: engineering education and sustainable community development. Eur J Eng Educ. 33(3):307-319. doi:10.1080/ 03043790802088640.
Seay JR. 2015. Education for sustainability: developing a taxonomy of the key principles for sustainable process and product design. Comput Chem Eng. 81:147-152.

Sharma B, Steward B, Ong SK, Miguez FE. 2017. Evaluation of teaching approach and student learning in a multidisciplinary sustainable engineering course. J Clean Prod. 142:4032-4040. doi:10.1016/j.jclepro.2016.10.046

Shiel C, Leal Filho W, Do Paço A, Brandli L. 2016. Evaluating the engagement of universities in capacity building for sustainable development in local communities. Eval Program Plann. 54:123-134. http://linkinghub.elsevier. com/retrieve/pii/S0149718915000804.

Shields D, Verga F, Andrea Blengini G. 2014. Incorporating sustainability in engineering education. Int J Sustain High Educ. 15(4):390-403. doi:10.1108/IJSHE-02-2013-0014.

Singh RK, Gupta A, Kumar A, Khan TA. 2016. Ranking of barriers for effective maintenance by using TOPSIS approach. J Qual Maint Eng. 22(1):18-34. doi:10.1108/ JQME-02-2015-0009.

Sivapalan S. 2016. Engineering education for sustainable development in Malaysia: student stakeholders perspectives on the integration of holistic sustainability competences within undergraduate engineering programmes. In: Leal Filho W, Brandli L, editors. Engaging Stakeholders in education for sustainable development at University Level. Cham: Springer International Publishing; p. 263-285. doi:10.1007/978- 3319-26734-0

Sivapalan S, Clifford MJ, Speight S. 2017 May. Engineering education for sustainable development: using online learning to support the new paradigms. Australas J Eng Educ. 4952:1-13. doi:10.1080/22054952.2017.1307592.

Soares N, Dias Pereira L, Ferreira J, Conceição P, Pereira Da Silva P. 2015. Energy efficiency of higher education buildings: a case study. Int J Sustain High Educ. 16(5):669-691. doi:10.1108/IJSHE-11-2013-0147.

Somsuk N, Laosirihongthong T. 2017. Prioritization of applicable drivers for green supply chain management implementation toward sustainability in Thailand. Int J Sustain Dev World Ecol. 24(2):175-191.

Svanström M, Sjöblom J, Segalàs J, Fröling M. 2018. Improving engineering education for sustainable development using concept maps and multivariate data analysis. J Clean Prod. 198:530-540. https://www.science direct.com/science/article/pii/S0959652618320377.

Tejedor G, Segalàs J, Rosas-Casals M. 2018. Transdisciplinarity in higher education for sustainability: how discourses are approached in engineering education. J Clean Prod. 175:29-37. http://linkinghub.elsevier. com/retrieve/pii/S0959652617327452.

Thürer M, Tomašević I, Stevenson M, Qu T, Huisingh D. 2018. A systematic review of the literature on integrating sustainability into engineering curricula. J Clean Prod. 181:608-617.

UN. 2015. Quality Education. Sustain Dev Goals. https:// www.un.org/sustainabledevelopment/sustainabledevelopment-goals/.

UNESCO. 2017. Education for sustainable development goals learning objectives [Internet]. Paris: United Nations Educational, Scientific and Cultural Organization. http:// www.unesco.org/open-access/terms-.

Yoon KP, Kim WK. 2017. The behavioral TOPSIS. Expert Syst Appl. 89:266-272. doi:10.1016/j.eswa.2017.07.045 